\title{
A Photovoltaic (Cell, Module, Array) Simulation and Monitoring Model using MATLAB ${ }^{\circledR} /$ GUI Interface
}

\author{
M.B. Eteiba \\ Department of \\ Electrical \\ Engineering, \\ Faculty of \\ Engineering, \\ Fayoum University \\ Fayoum, Egypt
}

\author{
E.T. El Shenawy \\ Solar Energy \\ Department, \\ National Research \\ Centre \\ El Behooth St., Dokki, \\ Giza, Egypt
}

\author{
J.H. Shazly \\ Department of \\ Electrical \\ Engineering, \\ Faculty of \\ Engineering, \\ Fayoum University \\ Fayoum, Egypt
}

\author{
A.Z. Hafez \\ Solar Energy \\ Department, \\ National Research \\ Centre \\ El Behooth St., Dokki, \\ Giza, Egypt
}

\begin{abstract}
This paper presents the implementation of a generalized photovoltaic simulation model using MATLAB®/GUI interface. The model is developed using basic circuit equations of the Photovoltaic (PV) cells including the effects of solar radiation and temperature changes. These effects added in real time operation simultaneously. Since the PV module has nonlinear characteristics, it is necessary to model it for the design and simulation of maximum power point for such system applications. Photovoltaic system characteristic curves as current - voltage (I-V) and power - voltage (P-V) characteristics are drawn according to values change of the temperature and solar radiation which observed in MATLAB®/GUI interface. The simulation results showed that these factors and the corresponding PV model influence the maximum power obtained from PV modules under operating conditions. The simulation model also presented the design of the array and the batteries of the load connected to the photovoltaic system.
\end{abstract}

\section{General Terms}

Simulation,Matlabinterface, Photovoltaic, Solar Energy

\section{Keywords}

Photovoltaic, Simulation, Monitoring, MATLAB ${ }^{\circledR} /$ GUI.

\section{INTRODUCTION}

It is known that the important factor for photovoltaic system is the cost of a system, and because of several kinds of the photovoltaic array we have the right to select the best array with the best efficiency and price. The popular types of materials are crystalline and thin films, which have differences in terms of light absorption efficiency, energy conversion efficiency, manufacturing technology and cost of production. Different kinds of crystalline materials like a mono-crystalline, polycrystalline are available [1].

In this paper, the current and the generated power by the photovoltaic array is calculated according to daily solar irradiation when the cases study in Egypt. According to the generated power of the PV array and the required energy for a typical building, the number of photovoltaic arrays is estimated then the cost of the solar system is calculated. System is simulated by MATLAB $® / G U I$ interface software, and the results are discussed. The simulation is about sizing in order to select the best array for photovoltaic system to have a optimize system according to size of the system [1].
PV arrays, controllers, battery storage, inverters, and load models have been proposed to predict the performance of a PV system under various load current profiles [2, 3 and 4].Several PV models were reviewed to select a suitable model for PV devices by considering adjustment errors at specific data points [5]. The reverse bias model was adopted to explain the breakdown effect of a PV cell with temperature [6]. A detailed terminal voltage model of a PV cell was proposed using the five-parameter model [7, 8]. Experimental verification was achieved using mono-crystalline PV modules to evaluate four- and five-parameter models $[9,10]$.

The strong correlation between module temperature and electrical terminal characteristics has also prompted significant research into thermal modelling of PV panels. Temperature dependant models of a PV panel were suggested $[11,12]$, considering heat radiation, heat convection, and power generation. Two dimensional thermal flows for PV panel plates were considered in PV panel models [13, 14]. Experimental verification depicting the dependence of panel output power and efficiency on temperature was achieved using commercial PV modules [10, 15, 16 and 17].

\section{OPERATING PRINCIPLE}

A PV cell is a semiconductor p-n device that produces current when irradiated. This is due to electron - hole pair forming in the semiconductor material that absorbs photons with energy exceeding the band-gap energy of the semiconductor material. The PV cell consists of front and back contacts attached to the semiconductor material, the contacts can collect the charge carriers (negatively charged electrons and positively charged holes) from the semiconductor $\mathrm{p}$ and $\mathrm{n}$ layers and supply the load with the generated current (DC) as described in Fig. 1. [18].

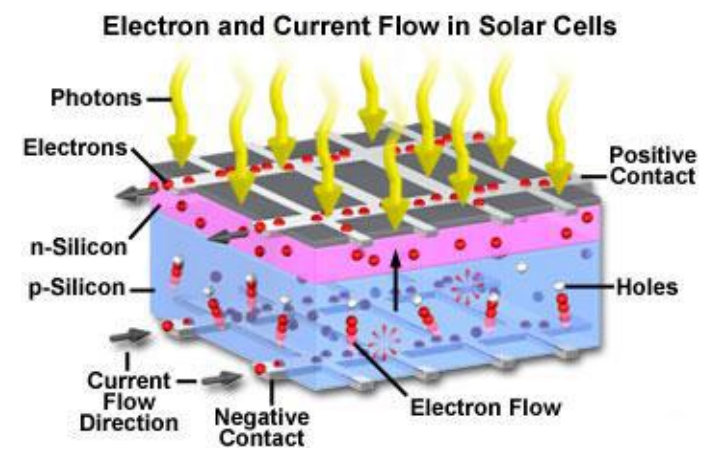

Fig. 1: The Process of generation electricity in PV cell 


\section{PHOTOVOLTAIC SYSTEM MODEL}

\subsection{Solar Cell Model}

The model is developed using basic circuit equations of the Photovoltaic (PV) Solar cells including the effects of solar irradiation and temperature changes. A PV cell can be represented by a current source connected in parallel with a diode, since it generates current when it is illuminated and acts as a diode when it is not. The equivalent circuit model also includes a shunt and series internal resistance that can be represented by resistors $R_{s}$ and $R_{s h}$ as shown in Fig. 2 .

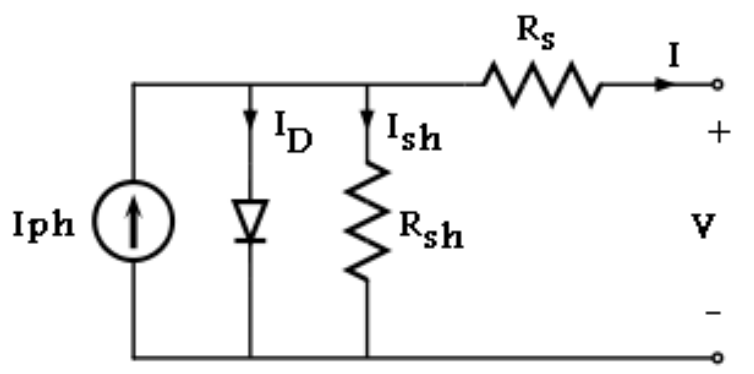

Fig. 2: The equivalent PV cell circuit model

The physical structure of a solar cell is similar to that of a diode in which the $\mathrm{p}-\mathrm{n}$ junction is subjected to sun exposure. The basic semi-conductor theory is captured in the following equations:

$$
\begin{aligned}
& I=I_{\text {ph,cell }}-I_{D} \\
& I_{D}=I_{o, \text { cell }} * \exp \left[\left(\frac{\mathbf{q V}}{\mathbf{A k T}_{\mathbf{c}}}\right)-\mathbf{1}\right]
\end{aligned}
$$

Where

\section{I: Cell output current, A}

$\mathrm{I}_{\text {ph,cell }}$ : The Photocurrent, isthe current produced by the incident light and function of irradiation level and junction temperature, A

$I_{D}$ : The diode current modeled by the equation for a Shockley diode, A

$\mathrm{I}_{\mathrm{O}, \mathrm{cell}}$ : The saturated reverse current or leakage current, A

$\mathrm{q}:$ Electron charge $\left(1.602 \times 10^{-19} \mathrm{C}\right)$.

$\mathrm{K}$ : Boltzmann constant $\left(1.38 \times 10-23 \mathrm{~J} /{ }^{\circ} \mathrm{k}\right)$

$\mathrm{V}$ : Cell output voltage, $\mathrm{V}$

$\mathrm{T}_{\mathrm{c}}$ : Cell operating temperature, ${ }^{\circ} \mathrm{k}$

A : The diode ideality factor

Eq. $(1,2)$ can be modified to obtain the current-voltage characteristics of a photovoltaic cell employed in the solar panel by adding some parameters as given in Equations (3, $4,5)[18,19]$.

$$
\begin{aligned}
& \mathbf{I}=\mathbf{I}_{\mathbf{p h}}-\mathbf{I}_{\mathbf{o}} * \exp \left[\left(\frac{\mathbf{q}\left(\mathbf{V}+\mathbf{I R}_{\mathbf{s}}\right)}{\mathrm{AKT}_{\mathrm{c}}}\right)-\mathbf{1}\right] \\
& -\left[\frac{\mathbf{V}+\mathbf{I R}_{\mathbf{s}}}{\mathbf{R}_{\mathbf{s h}}}\right] \\
& V=\frac{\mathbf{A K T}_{\mathbf{c}}}{\mathbf{q}} \ln \left[\frac{\mathbf{I}_{\mathrm{ph}}+\mathbf{I}_{\mathrm{o}}-\mathbf{I}}{\mathbf{I}_{\mathrm{o}}}\right]-\mathrm{IR}_{\mathbf{s}}(\mathbf{4})
\end{aligned}
$$

$$
\begin{aligned}
& \begin{array}{l}
\mathbf{I}=\mathbf{I}_{\mathbf{p h}}-\mathbf{I}_{\mathbf{o}} * \exp \left[\left(\frac{\left(\mathbf{V}+\mathbf{I R}_{\mathbf{s}}\right)}{A \mathbf{V}_{\mathbf{t}}}\right)-\mathbf{1}\right] \\
\quad-\left[\frac{\mathbf{V}+\mathbf{I R}_{\mathbf{s}}}{\mathbf{R}_{\mathbf{s h}}}\right] \\
\mathbf{V}_{\mathbf{t}}=\frac{\mathbf{N}_{\mathbf{s}} \mathbf{K} \mathbf{T}_{\mathbf{c}}}{\mathbf{q}}
\end{array} \\
& \text { Where }
\end{aligned}
$$

$\mathrm{I}_{\mathrm{ph}}$ : Photocurrent, The photovoltaic current, A

$\mathrm{I}_{\mathrm{o}}$ : Reverse saturation current, A

$\mathrm{R}_{\mathrm{S}}$ : Series resistance of the cell, $\Omega$

$\mathrm{R}_{\mathrm{sh}}$ : Shunt resistance of the cell, $\Omega$

$\mathrm{V}_{\mathrm{t}}$ : Thermal voltage, $\mathrm{V}$

$\mathrm{N}_{\mathrm{S}}$ : Number of series cells

$\mathrm{N}_{\mathrm{p}}$ : Number of parallel cells branches

Both $\mathrm{K}$ and $\mathrm{T}_{\mathrm{c}}$ should have the same temperature unit, in Kelvin. The curve fitting factor $\mathrm{A}$ is used to adjust the I-V characteristics of the cell obtained by testing.

Equations (3) \& (4) give the voltage of a single solar cell which is then multiplied by the number of cells connected in series to calculate the full array voltage. Since the array current is the sum of the currents flowing through the cells in parallel branches, the cell current I is obtained by dividing the array current by the number of the cells connected in parallel before being used in eq. (4), which is only valid for a certain cell operating temperature $T_{c}$ with its corresponding solar irradiation level G [20, 21].

If the temperature and solar irradiation levels change, the voltage and current outputs of the PV array will follow this change. Hence, the effects of the changes in temperature and solar irradiation levels should also be included in the final PV array model. A method to include these effects in the PV array modelling is given by Buresch [20]. According to his method, for a known temperature and a known solar irradiation level, a model is obtained and then this model is modified to handle different cases of temperature and irradiation levels. Let (9) be the benchmark model for the known operating temperature $\left(\mathrm{T}_{\mathrm{c}}\right)$ and known solar irradiation level $(\mathrm{G})$ as given in the specification. [21, 22]

When the ambient temperature and irradiation levels change, the cell operating temperature also changes, resulting in a new output voltage and a new photocurrent value. The solar cell operating temperature varies as a function of solar irradiation level and ambient temperature. The variable ambient temperature $T_{a}$ affects the cell output voltage and cell photocurrent. These effects are represented in the model by the temperature coefficients $\mathrm{K}_{\mathrm{i}}$ and $\mathrm{K}_{\mathrm{o}}$ for cell output voltage and cell photocurrent, [15] respectively, as:

$$
T_{c}=\left[\frac{N O C T-20}{0.8}\right] \times G+T_{a}
$$

NOCT: Nominal operating cell temperature

$\mathrm{I}_{\mathrm{ph}}$ exhibits a linear relationship with light intensity. $\mathrm{I}_{\mathrm{o}}$ is also temperature dependent. Values of $\mathrm{I}_{\mathrm{ph}}$ and $\mathrm{I}_{\mathrm{o}}$ are given by the following equations [18]:

$\mathbf{I}_{\mathbf{p h}}=\left[\mathbf{I}_{\mathbf{p h r}}+\mathbf{K}_{\mathbf{i}} \mathbf{x}\left(\mathbf{T}_{\mathbf{c}}-\mathbf{T}_{\mathbf{r}}\right)\right] \mathbf{x}\left(\frac{\mathbf{G}}{\mathbf{G}_{\mathbf{r}}}\right)$ 


$$
I_{o}=\left[I_{o r} \times\left(\frac{T_{c}}{T_{r}}\right)^{3}\right] \exp \left[\frac{q E_{g}}{k A} \times\left(\frac{1}{T_{r}}-\frac{1}{T_{c}}\right)\right]
$$

Where

$\mathrm{I}_{\mathrm{ph}}$ : The photovoltaic current at $\mathrm{T}_{\mathrm{c}} \& \mathrm{G}, \mathrm{A}$

$\mathrm{I}_{\mathrm{phr}}$ : The photovoltaic current under standard conditions at $\mathrm{T}_{\mathrm{r}} \& \mathrm{G}_{\mathrm{r}}, \mathrm{A}$

$I_{o}$ : Reverse saturation current at $T_{c}, A$

$I_{\text {or }}$ : Reverse saturation current at reference temperature at $T_{r}$, A

G : The intensity of solar irradiance, $\mathrm{W} / \mathrm{m}^{2}$

$\mathrm{G}_{\mathrm{r}}$ : The reference intensity of solar irradiance $=1000 \mathrm{~W} / \mathrm{m}^{2}$

$\mathrm{K}_{\mathrm{i}}$ : Temperature coefficient of the short circuit current

$\mathrm{K}_{\mathrm{o}}$ : Temperature coefficient of the open circuit voltage

$\mathrm{T}_{\mathrm{c}}$ : Cell operating temperature, ${ }^{\circ} \mathrm{k}$

$\mathrm{T}_{\mathrm{r}}$ : Reference cell operating temperature $=25^{\circ} \mathrm{C}=298.13^{\circ} \mathrm{k}$

$\mathrm{T}_{\mathrm{a}}$ : Ambient air temperature, ${ }^{\mathrm{o}} \mathrm{k}$

$E_{\mathrm{g}}$ : Band-gap of the semiconductor material

The saturated reverse current, $\mathrm{I}_{\mathrm{or}}$, at reference temperature at $T_{r}$ is given by the following equation [18]:

$$
I_{\text {or }}=\left[\frac{I_{\text {scr,Cell }}}{\exp \left(\frac{V_{\text {ocr,Cell }}}{A V_{t}}\right)}\right]
$$

Where

$I_{\text {scr,Cell }}$ : Short circuit current of photovoltaic cell under standard conditions at $\mathrm{T}_{\mathrm{r}} \& \mathrm{G}_{\mathrm{r}}, \mathrm{A}$

$\mathrm{V}_{\text {ocr,Cell }}$ : Open circuit voltage of photovoltaic cell under standard conditions at $\mathrm{T}_{\mathrm{r}} \& \mathrm{G}_{\mathrm{r}}, \mathrm{V}$

The open circuit voltage and short circuit current are important parameters associated with the $\mathrm{I}-\mathrm{V}$ characteristics of the solar panel. These parameters are subject to variations in the atmospheric conditions. The short circuit current and open circuit voltage can be calculated under different atmospheric conditions using the following equations [18]:

$$
\begin{aligned}
& \mathbf{I}_{\text {sc,Cell }}=\left[\mathbf{I}_{\text {scr,Cell }}+\mathbf{K}_{\mathbf{i}} \times\left(\mathbf{T}_{\mathbf{c}}-\mathbf{T}_{\mathbf{r}}\right)\right] \times\left(\frac{\mathbf{G}}{\mathbf{G}_{\mathbf{r}}}\right)(\mathbf{1 1}) \\
& \mathbf{V}_{\text {oc,Cell }}=\left[\mathbf{V}_{\mathrm{ocr}, \text { Cell }}+\mathbf{K}_{\mathbf{v}} \times\left(\mathbf{T}_{\mathbf{c}}-\mathrm{T}_{\mathbf{r}}\right)\right]
\end{aligned}
$$

Where

$\mathrm{I}_{\mathrm{sc}, \text { Cell }}$ : Short circuit current of photovoltaic cell under operating conditions at $\mathrm{T}_{\mathrm{c}} \& \mathrm{G}, \mathrm{A}$

$\mathrm{V}_{\mathrm{oc}, \text { Cell }}$ : Open circuit voltage of photovoltaic cell under operating conditions at $\mathrm{T}_{\mathrm{c}} \& \mathrm{G}, \mathrm{V}$

Equations $(3,4)$ represent $\mathrm{I}-\mathrm{V}$ and $\mathrm{P}-\mathrm{V}$ curves, where three remarkable points are highlighted [23]:
a) open- circuit $\left(\mathrm{V}_{\mathrm{oc}}, 0\right)$,
b) Short circuit $\left(0, I_{s c}\right)$,
c) Maximum power point $\left(\mathrm{V}_{\mathrm{MP}}, \mathrm{I}_{\mathrm{MP}}\right)$.

\subsubsection{Open-circuit}

This point is obtained when the terminals of the cell are disconnected. The cell presents a voltage called $\left(\mathrm{V}_{\mathrm{oc}}\right)$ expressed analytically using eq. (13).

$$
\mathbf{V}=\frac{\mathbf{A K T}_{\mathbf{c}}}{\mathbf{q}} \ln \left[\frac{\mathbf{I}_{\mathbf{p h}}}{\mathbf{I}_{\mathbf{o}}}\right]
$$

\subsubsection{Short-circuit}

The terminals of the cell are short circuited, through which flows a current called $\left(\mathrm{I}_{\mathrm{sc}}\right)$. In this situation, the voltage between cell terminals is zero.

$$
\mathbf{I}_{\mathbf{s c}}=\mathbf{I}_{\mathbf{P h}}=\mathbf{c} * \mathbf{G}
$$

Where $\mathrm{c}$ is a constant.

\subsubsection{Maximum power point (MPP)}

It is the operating point on the I-V curve that gives the maximum output power from the solar cell at different operating conditions.Here voltage versus current product which produce maximum values of power points. $\mathrm{V}_{\mathrm{MP}}$ is related to $\mathrm{V}_{\mathrm{OC}}$ through the relation in eq. (15):

$$
\mathrm{V}_{\mathrm{MP}} \approx 0.8 * \mathrm{~V}_{\mathrm{oc}}(\mathbf{1 5})
$$

And $\mathrm{I}_{\mathrm{MP}}$ is related to $\mathrm{I}_{\mathrm{sc}}$ through the relation in eq. (16):

$$
\mathrm{I}_{\mathrm{MP}} \approx 0.8 * \mathrm{I}_{\mathrm{sc}}(\mathbf{1 6})
$$

The best conditions are the "standard operating conditions" happen at Irradiance equal to $1000 \mathrm{~W} / \mathrm{m}^{2}$, cells temperature equals to $25^{\circ} \mathrm{C}$, and spectral distribution (Air Mass) $\mathrm{AM}$ is equal to 1.5 .

\subsection{Solar Module Model}

To increase total voltage of the module, cells have to be connected in series as shown in Fig. $3\left(V_{\text {out }}=V_{1}+V_{2}+V_{3}+\ldots\right)$. Connecting PV cells in parallel, as shown in Fig. 4, increases the total current generated by the module $\left(\mathrm{I}_{\text {out }}=\mathrm{I}_{1}+\mathrm{I}_{2}+\mathrm{I}_{3}+\ldots\right)$. The total current is equal to sum of current produced by each cell.

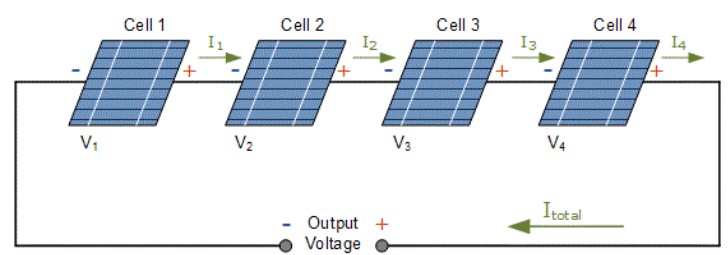

Fig. 3: Connecting PV cells in series

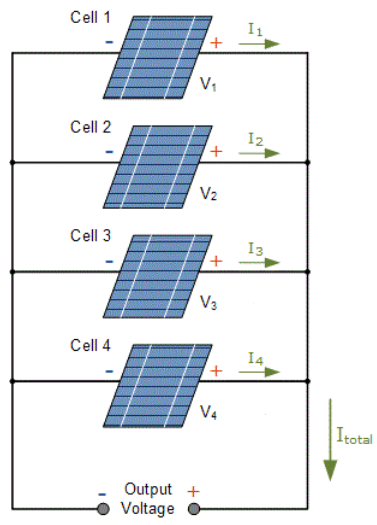

Fig. 4: Connecting PV cells in parallel 
For $\mathrm{N}_{\mathrm{p}}$ cells branches in parallel and $\mathrm{N}_{\mathrm{s}}$ cells in series, the total shunt resistances $\left(\mathrm{R}_{\text {sh,Module }}\right)$ and series resistances $\left(\mathrm{R}_{\mathrm{s}, \text { Module }}\right)$ in module are equal to:

$$
\begin{aligned}
& \mathbf{R}_{\text {sh,Module }}=\left(\frac{\mathbf{N}_{\mathbf{p}}}{\mathbf{N}_{\mathbf{s}}}\right) \times \mathbf{R}_{\text {sh,Cell }} \\
& \mathbf{R}_{\mathbf{s}, \text { Module }}=\left(\frac{\mathbf{N}_{\mathbf{s}}}{\mathbf{N}_{\mathbf{p}}}\right) \times \mathbf{R}_{\mathrm{s}, \text { Cell }}
\end{aligned}
$$

Where

$\mathrm{R}_{\text {sh,Module }}$ : Total shunt resistance in the photovoltaic module, Ohm.

$\mathrm{R}_{\mathrm{s}, \text { Module }}$ : Total series resistance in the photovoltaic module, Ohm.

$\mathrm{R}_{\text {sh,Cell }}$ : Shunt resistance in one photovoltaic cell, Ohm.

$\mathrm{R}_{\mathrm{s}, \text { Cell }}:$ Series resistance in one photovoltaic cell, Ohm.

$\mathrm{N}_{\mathrm{s}}$ : Number of cells in series

$\mathrm{N}_{\mathrm{p}}$ : Number of cells branches in parallel

Then, we will add $R_{s, \text { Module }} \& R_{\text {sh,Module }}$ in eq. ( $\left.3 \& 4\right)$ instead of $R_{s} \& R_{\text {sh }}$ respectively if the module have $N_{s} \& N_{p}$, then apply equations in previous sections to find specifications of the module and draw characteristic as current - voltage (I-V) characteristics \& power - voltage (P-V) characteristics, which are drawing according to the values of the temperature and solar radiation are observed in MATLAB ${ }^{\circledR} /$ GUI interface [24, 25].

The module current has an implicit expression depending on the following variables expressed in function of a single cell parameters and this is approximation method [26]:

$$
\begin{aligned}
& I_{s c, \text { Module }}=N_{p} \cdot I_{s c, \text { Cell }} \\
& V_{o c, \text { Module }}=N_{s} \cdot V_{o c, \text { Cell }}
\end{aligned}
$$

Where

$I_{\mathrm{sc}, \text { Module }}$ : Total short circuit current of the photovoltaic module, $\mathrm{A}$.

$\mathrm{V}_{\text {oc,Module }}$ : Total open circuit voltage of the photovoltaic module, $\mathrm{V}$.

$\mathrm{I}_{\mathrm{sc}, \text { Cell }}$ : Short circuit current of one photovoltaic cell

$\mathrm{V}_{\mathrm{oc}, \text { Cell }}$ : Open circuit voltage of one photovoltaic cell

\subsection{Solar Array Model}

The modules in a PV system are typically connected in arrays.Fig. 5.Illustrates the case of an array with $\mathrm{M}_{P}$ parallel branches each with $\mathrm{M}_{\mathrm{S}}$ modules in series.

The applied voltage at the array's terminals is denoted by $\mathrm{V}^{\mathrm{A}}$, while the total current of the array is denoted by

$$
(\mathbf{I})^{\mathbf{A}}=\sum_{\mathbf{i}=\mathbf{0}}^{\mathbf{M p}} \mathbf{I}_{\mathbf{i}}
$$

Where $\mathrm{A}$ is the branches number
If it is assumed that the modules are identical and the ambient irradiation is the same on all the modules, then the array's current is:

$\mathbf{I}^{\mathbf{A}}=\mathbf{M}_{\mathbf{p}} \mathbf{I}^{\mathbf{M}}$

From load data is inserted in simulation program, we can specify the data \& number of connection of photovoltaic array system.

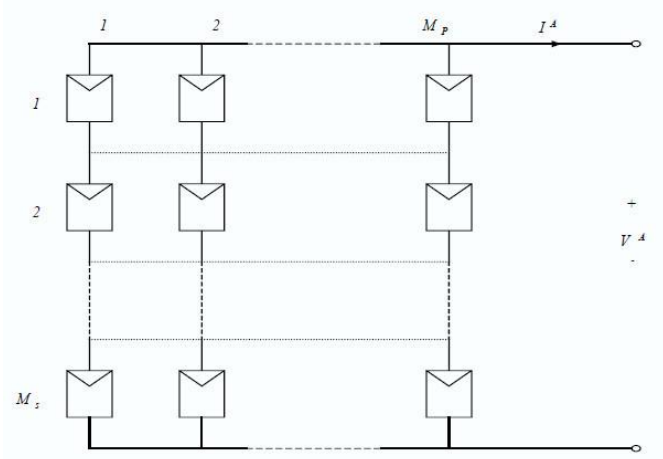

Fig. 5: Solar cell array consists of $M_{p}$ parallel branches, with $M_{s}$ Modules in series in each branch.

\subsection{Design of the system}

In one day, the Load will consume energy (E) in Wh/day

$\mathbf{E}=\mathbf{P}_{\mathbf{L}} \mathbf{x} \mathbf{T}_{\mathbf{o}}$

Where

$\mathrm{P}_{\mathrm{L}}$ : Power of load, $\mathrm{W}$

$\mathrm{T}_{\mathrm{o}}$ : Operating time of load, hours

The connected load $\left(\mathrm{I}_{\text {conn. }}\right)$ in $(\mathrm{Ah})$ is calculated by:

$\mathbf{I}_{\text {conn. }}=\mathbf{I} \times \mathbf{T}_{\mathbf{o}}=\frac{\mathbf{E}}{\mathbf{V}}$

If the current is not constant, the current must be integrated over the time operation.

Neither the battery charging and discharging nor the wiring is $100 \%$ efficient. Charging \& discharging efficiency of battery and wiring efficiency are inserted.

The corrected load $\left(\mathrm{I}_{\text {corr. }}\right)$ in $(\mathrm{Ah})$ is calculated by:

$I_{\text {corr. }}=\frac{I_{\text {conn. }}}{\eta_{\text {all }}}$
$\eta_{\text {all }}=\eta_{b} \times \eta_{w}$

Where

$\eta_{\text {all }}:$ All efficiency

$\eta_{\mathrm{b}}:$ Battery efficiency

$\eta_{\mathrm{w}}$ : Wiring efficiency

The batteries capacity BC in (Ah) is calculated by:

$\mathbf{B}_{\mathbf{C}}=\frac{\mathbf{I}_{\text {corr }}}{\mathbf{B}_{\mathbf{D}}}$

$\mathrm{B}_{\mathrm{D}}$ : Battery depth of charging \& discharging 
This capacity might be designed as Ampere - hour capacity \& Voltage of battery

Specify the PV power needs. It is determined by determining the time when the least amount of sunlight is available during months. During the longest hour period, the PV array must produce all the electricity needed to operate the load for a day.

It must be taken into account that the PV modules may not always operate at peak efficiency, such as if they get dusty, or operation at cell temperatures higher than $25{ }^{\circ} \mathrm{C}$ may reduce maximum output power by an additional.

The PV array output current (on one day)

$=\frac{\mathbf{I}_{\text {corr. }}}{\operatorname{Psh} \times \eta_{p v}}$

$\mathrm{I}_{\text {corr. }}$ : The corrected load, Ah

$\eta_{\mathrm{pv}}$ : Photovoltaic module efficiency

Psh : Peak sun hour, hours

\section{No. of modules in series}

$$
\geq \frac{\text { Voltage of System inserted }}{\text { Voltage of one module }}
$$

$\begin{aligned} & \text { No. of modules in parallel } \\ & \text { Current needed to load }\end{aligned}$
$\geq \frac{\text { Current of one module }}{\text { Curente }}$

\section{MATHEMATICAL MODELLING CALCULATION TECHNIQUE BY NEWTON-RAPHSON ALGORITHM}

The Newton-Raphson method, or Newton Method, is a powerful technique for solving equations numerically. Like so much of the differential calculus, it is based on the simple idea of linear approximation. The Newton Method, properly used, usually homes in on a root with devastating efficiency.

If $x_{n}$ is the current estimate, then the next estimate $x_{n+1}$ is given by

$\mathbf{x}_{\mathbf{n}+1}=\mathbf{x}_{\mathbf{n}}-\frac{\mathbf{f}\left(\mathbf{x}_{\mathbf{n}}\right)}{\grave{\mathbf{f}}\left(\mathbf{x}_{\mathbf{n}}\right)}$

The Newton-Raphson method is used to solve systems of nonlinear equations. It find the roots of a nonlinear function by computing the Jacobian linearization of the function around an initial guess point, and using this linearization to move closer to the nearest zero. A set of nonlinear equations applying in equations $(3,4)$ and are illustrated in Fig. 6.

\section{MATLAB ${ }^{\circledR} /$ GUI INTERFACING}

The generalized photovoltaic simulation model using MATLAB ${ }^{\circledR} /$ GUI interface \& adding design of photovoltaic array system are explained in this paper. The model is developed using basic circuit equations of the Photovoltaic (PV) Solar cells including the effects of solar radiation and temperatures changes. These effects in photovoltaic module added in real time operation simultaneously. Since the PV module has nonlinear characteristics, it is necessary to model it for the design and simulation of maximum power point tracking (MPPT) for PV system applications. The characteristic curves as the current - voltage (I-V) characteristics \& the power - voltage $(\mathrm{P}-\mathrm{V})$ characteristics are shown according to the values of the temperature and solar radiation are observed in MATLAB ${ }^{\circledR} / \mathrm{GUI}$ interface. The simulation results also show that these factors and the corresponding PV model influence the power obtained from PV modules.

The Lorentz LC80-12M PV module was chosen for modelling, The module provides 80 watt of nominal maximum power, and has 36 monocrystalline series connected silicon cells. The key specifications are shown in Table 1. The input data are inserted in simulation GUI/Interface matlab model as shown in Figure (7).

The model of the PV module was implemented using a Matlab program. The model parameters are evaluated during execution using the equations listed on the previous sections. The program also, calculate the current I, using typical electrical parameter of the cell or module $\left(\mathrm{I}_{\mathrm{sc}}, \mathrm{V}_{\mathrm{oc}}\right)$, and the variables Voltage, Irradiation $(\mathrm{G})$, and Temperature $(\mathrm{T})$.

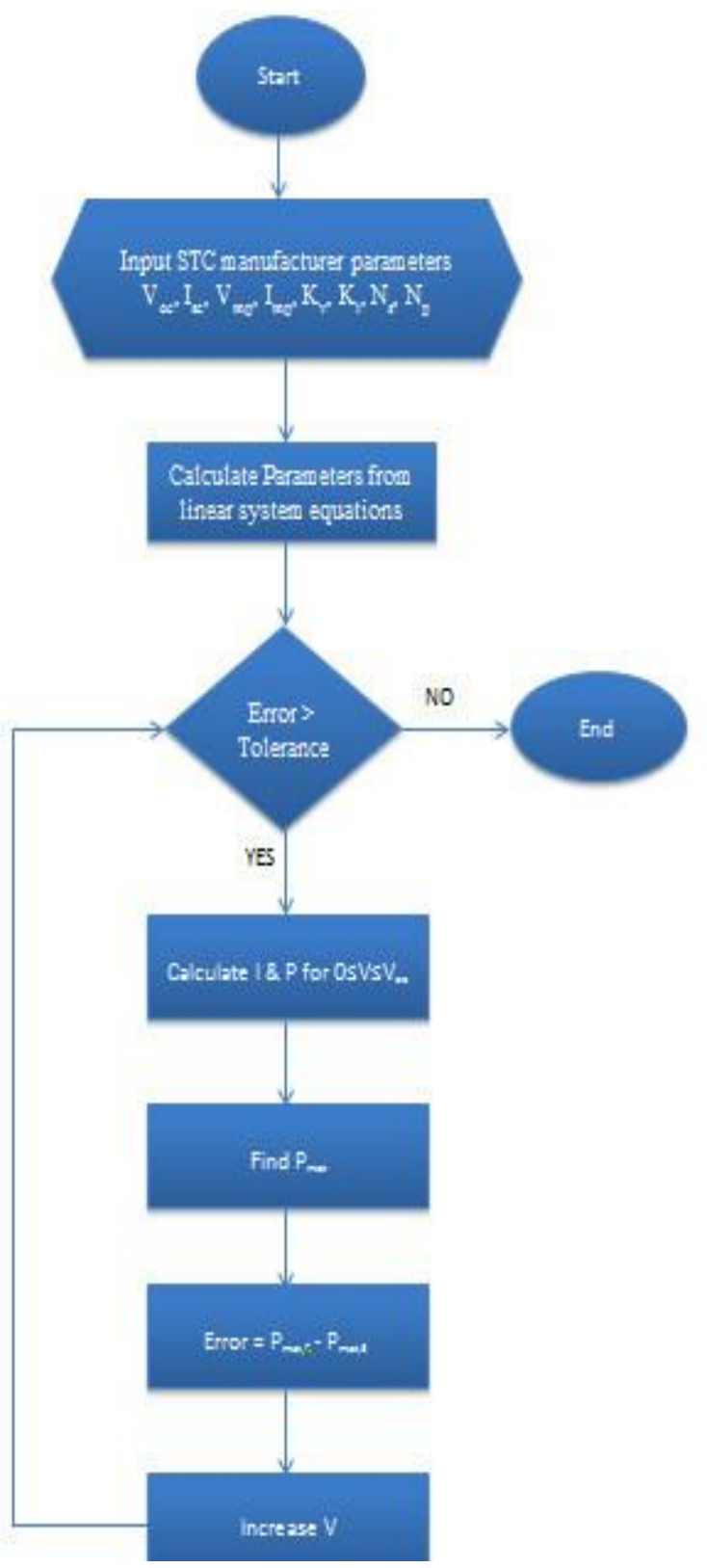

Fig.6: Flowchart display mathematical modelling calculation technique by Newton-Raphson Algorithm. 
Table 1:Specifications of Lorentz LC80-12M PV Module at at standard test condition $\left(1000 \mathrm{~W} / \mathrm{m}^{2}, 25{ }^{\circ} \mathrm{C}\right)$

\begin{tabular}{|c|c|c|}
\hline Parameter & Variable & Value \\
\hline Maximum Power & $P_{m}$ & $80 W$ \\
\hline Voltage@Pm & $V_{m}$ & $17.2 \mathrm{~V}$ \\
\hline Current@Pm & $I_{m}$ & $4.6 A$ \\
\hline Short circuit current & $I_{S C}$ & $5 A$ \\
\hline Open-circuit voltage & $V_{O C}$ & $22.4 \mathrm{~V}$ \\
\hline $\begin{array}{l}\text { Temperature coefficient } \\
\text { of open circuit } \\
\text { voltage }\end{array}$ & ko & $-(0.35) \% /{ }^{\circ} C$ \\
\hline $\begin{array}{l}\text { Temperature coefficient } \\
\text { of short circuit } \\
\text { current }\end{array}$ & $k i$ & $(0.09) \% /{ }^{\circ} \mathrm{C}$ \\
\hline $\begin{array}{l}\text { Temperature coefficient } \\
\text { of power }\end{array}$ & & $-(0.5)$ \\
\hline
\end{tabular}

\section{RESULTS}

Simulation Matlab GUI/Interface model showed (I-V) and (P$\mathrm{V})$ characteristic curves in figures $(8,9)$ for the PV system and batteries under connecting the desired load at ambient temperature ansolar radiation level of operating conditions.

Figures (10(a), 10(b)) shows the changesin the (I-V) curve changes depending on solar radiation $\mathrm{G}$ for $\left(1 \mathrm{KW} / \mathrm{m}^{2}\right) \&($ $\left.0.8 \mathrm{KW} / \mathrm{m}^{2}\right) \&\left(0.6 \mathrm{KW} / \mathrm{m}^{2}\right) \&\left(0.4 \mathrm{KW} / \mathrm{m}^{2}\right) \&(0.2$ $\mathrm{KW} / \mathrm{m}^{2}$ ), while ambient temperature $\left(\mathrm{T}_{\mathrm{a}}\right)$ is constant and equal to $25^{\circ} \mathrm{C}$, this will lead to in the short circuit current is equal to $5.2 \mathrm{~A}$, given that $\mathrm{N}_{\mathrm{s}}=36, \mathrm{~N}_{\mathrm{p}}=1$ and solar radiation equal to $\left(1 \mathrm{KW} / \mathrm{m}^{2}\right)$. The maximum current $\left(\mathrm{I}_{\max }\right)$ of the PV module is $4.6 \mathrm{~A}$ and the maximum voltage $\left(\mathrm{V}_{\max }\right)$ is $17.2 \mathrm{~V}$ which corresponding the maximum power $\left(\mathrm{P}_{\max }\right)$ is $68.16 \mathrm{~W}$. Since short circuit current is directly proportional to solar radiation, the characteristic curves in Figure (11) show the predicted response to the change of irradiation.

Figures (11(a), 11(b)) shows the changes of the (P-V) characteristic curve depending on solar radiation $(G)$ when ambient temperature (Ta) is constant and equal to $25^{\circ} \mathrm{C}$, this will lead to increasing in maximum output power as increasing in solar radiation.

Graphs in Figure (12(a),12(b))showed the changes in the (I-V) characteristic curve with the ambient temperature when the solar radiation is constant $\left(1 \mathrm{kw} / \mathrm{m}^{2}\right)$. Ambient temperature has a highly effect in open circuit voltage. Open circuit voltage of each cell reduces by approximately $0.23 \mathrm{mV}$ for every $1^{\circ} \mathrm{C}$ increase in ambient temperature. Short circuit current increases lightly as ambient temperature increases, but not enough to compensate the power loss due to decreasing in open circuit voltage.

Figures (13(a), 13(b)) showed the changesof the (P-V) characteristic curve with ambient temperature increases and when solar radiation is constant $\left(1 \mathrm{kw} / \mathrm{m}^{2}\right)$. Ambient temperature has a highly effect in open circuit voltage and maximum output power

Figures $(14,15)$ showed the effects of solar radiation \& temperature changes in real time operation in (I-V) characteristics \& $(\mathrm{P}-\mathrm{V})$ characteristics of $\mathrm{PV}$ Module.

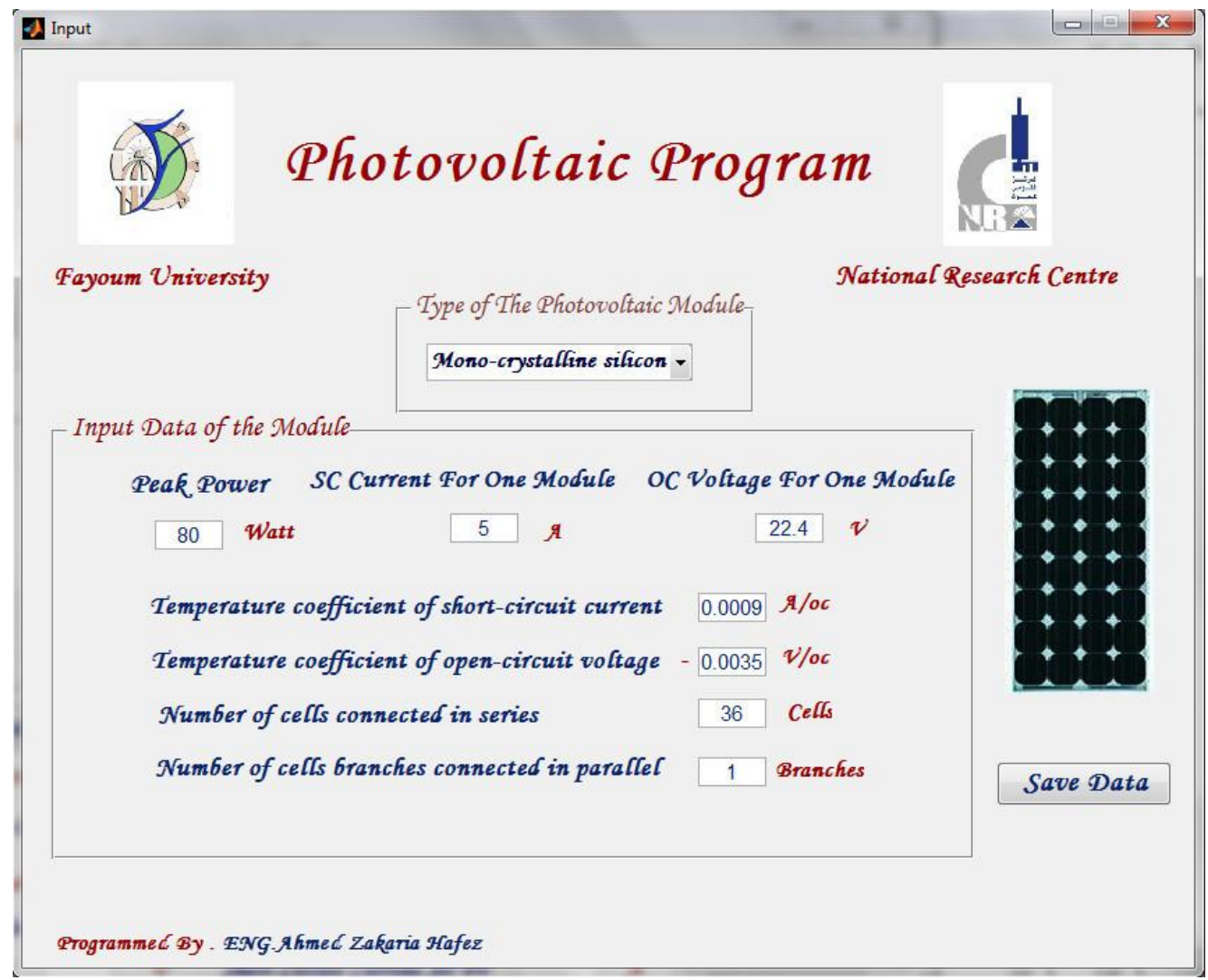

Fig. 7: Input data of PV Module 


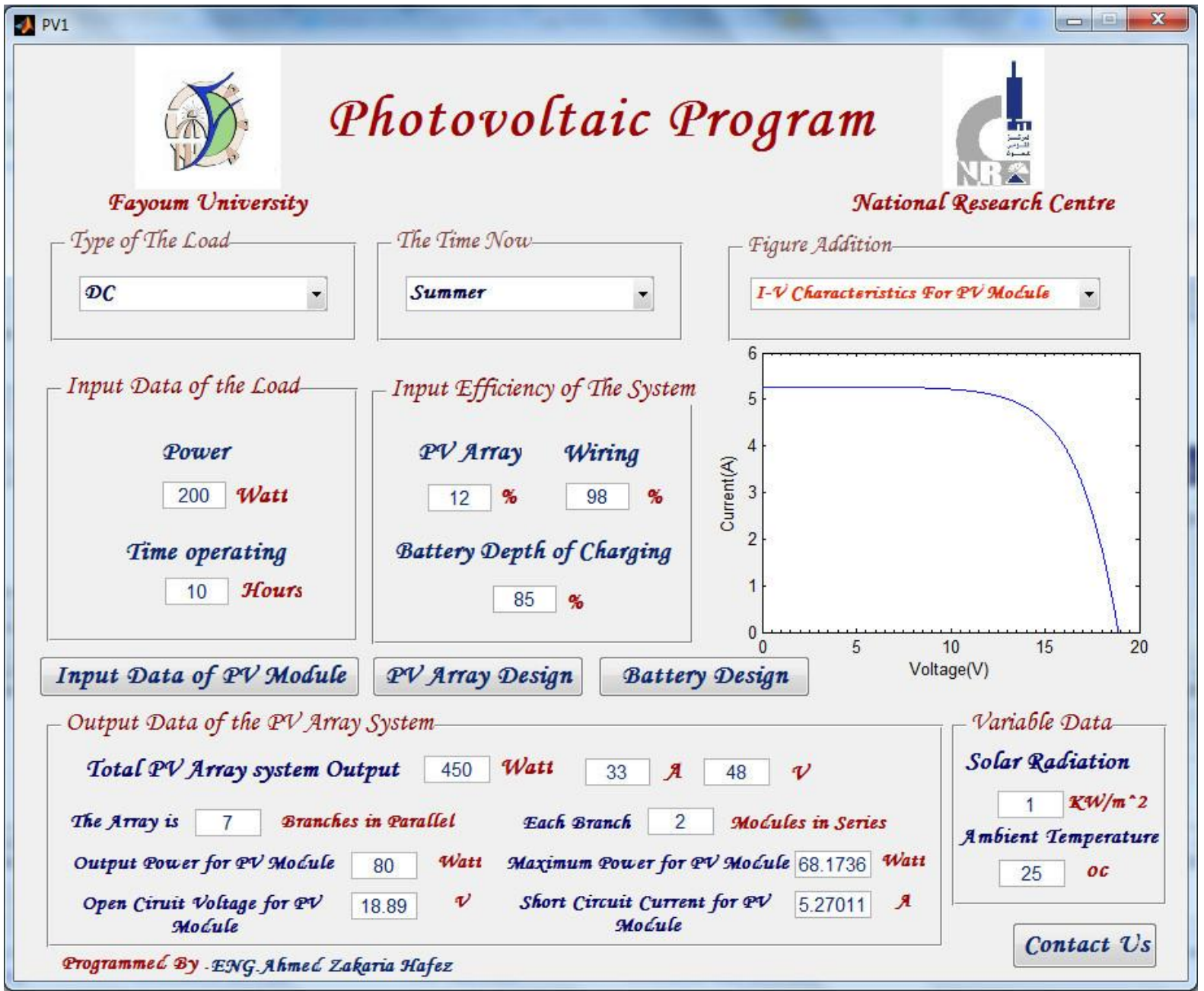

(a)

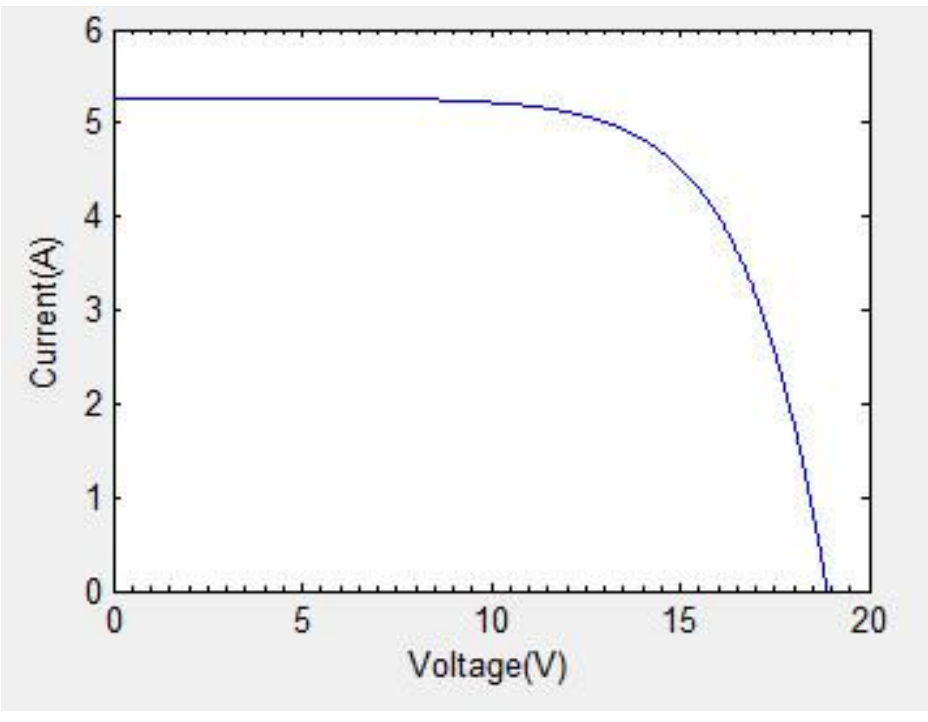

(b)

Fig. 8: Simulation model for (I-V) characteristics of PV Module

(a) Matlab GUI/Interface simulation model (b) (I-V) characteristics figure of PV Module 


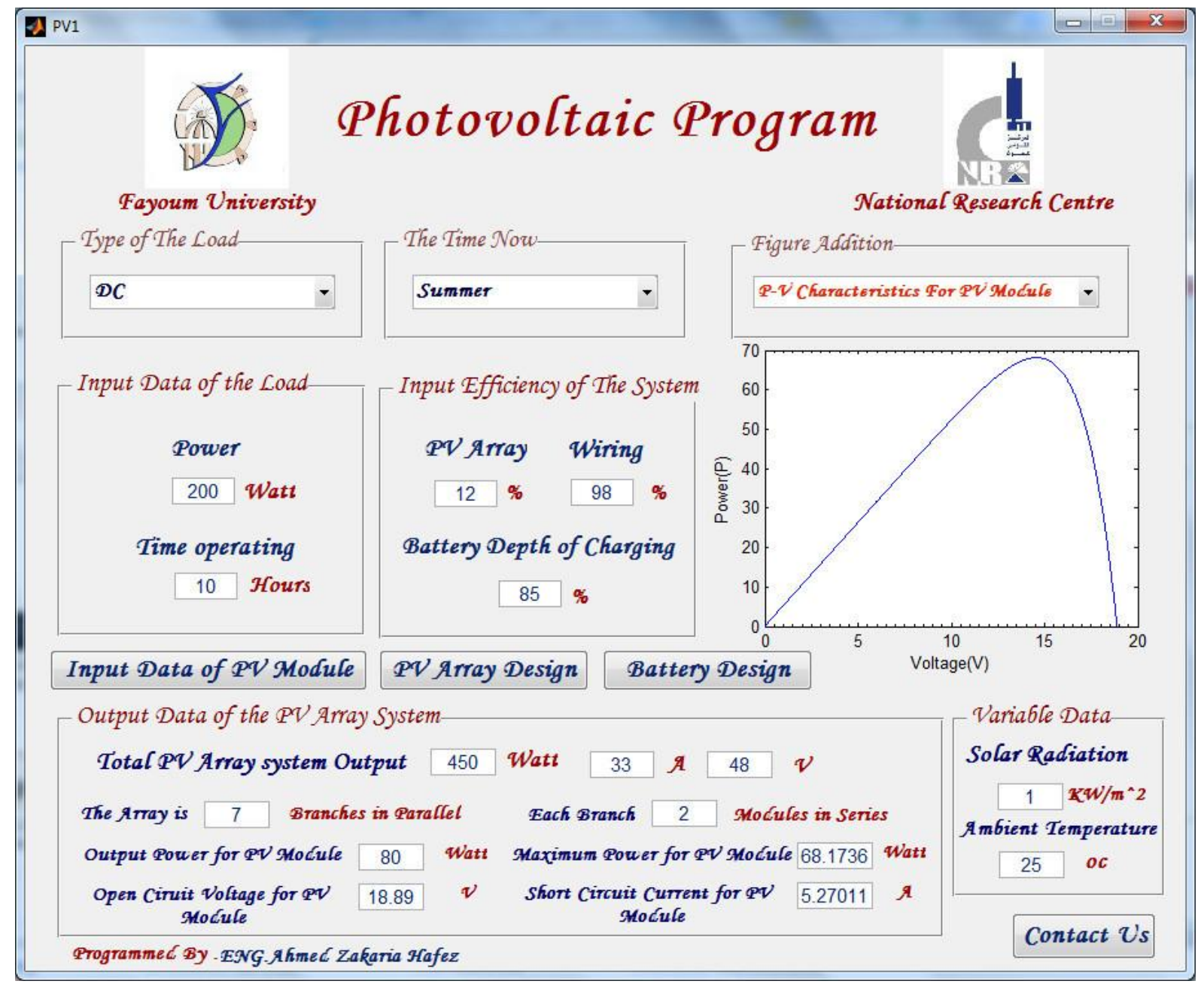

(a)

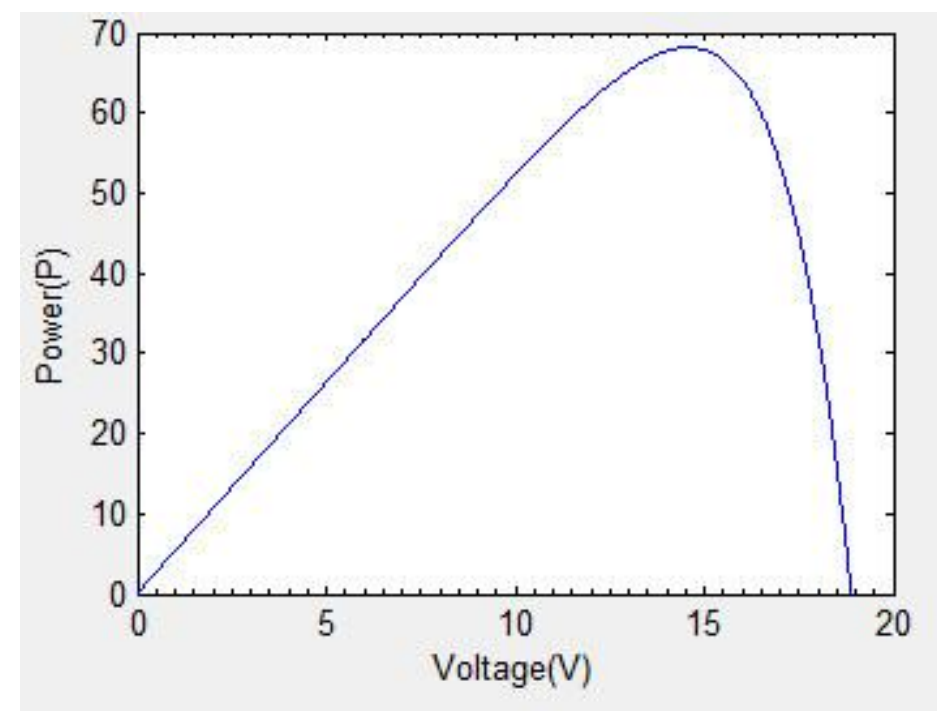

(b)

Fig. 9: Simulation model for (P-V) characteristics of PV Module

(a) Matlab GUI/Interface simulation model (b) (P-V) characteristics figure of PV Module 


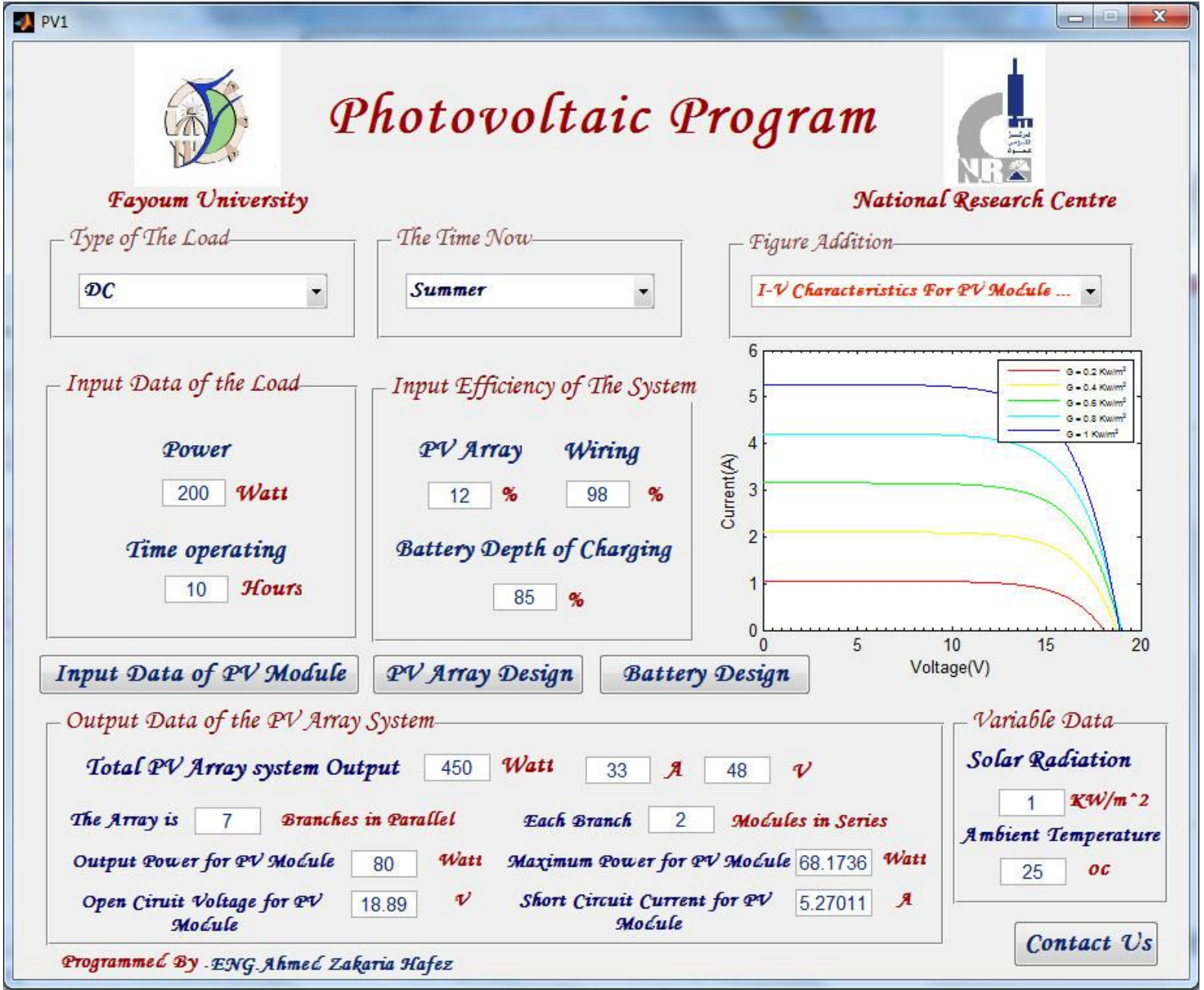

(a)

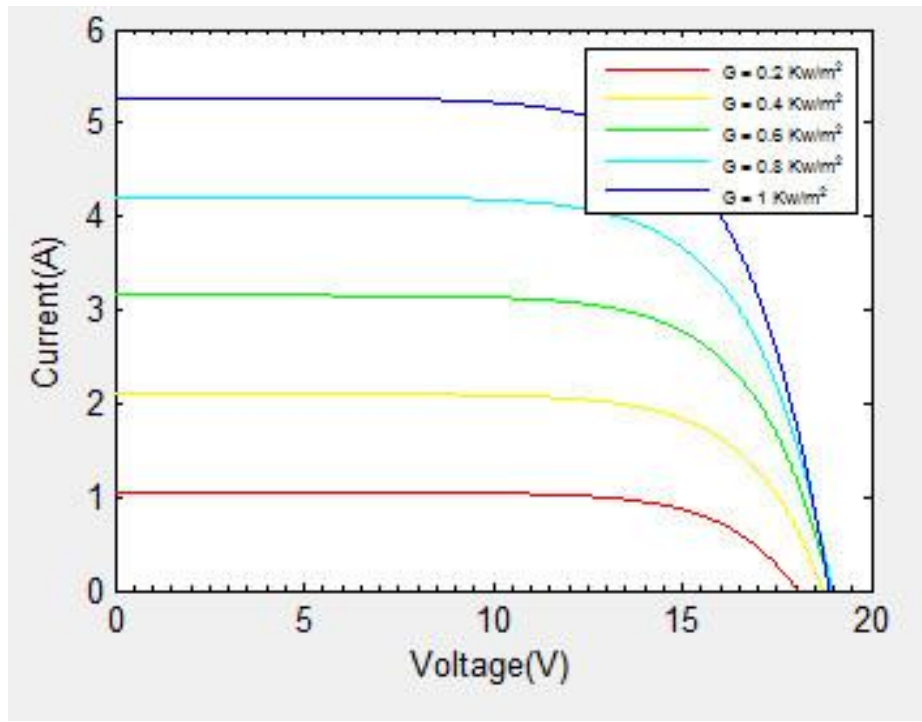

(b)

Fig. 10: Effects of solar radiation changes in (I-V) characteristics of PV Module at constant temperature $\left(25^{\circ} \mathrm{C}\right)$

(a) Matlab GUI/Interface simulation model (b) (I-V) characteristics figures of PV Module 


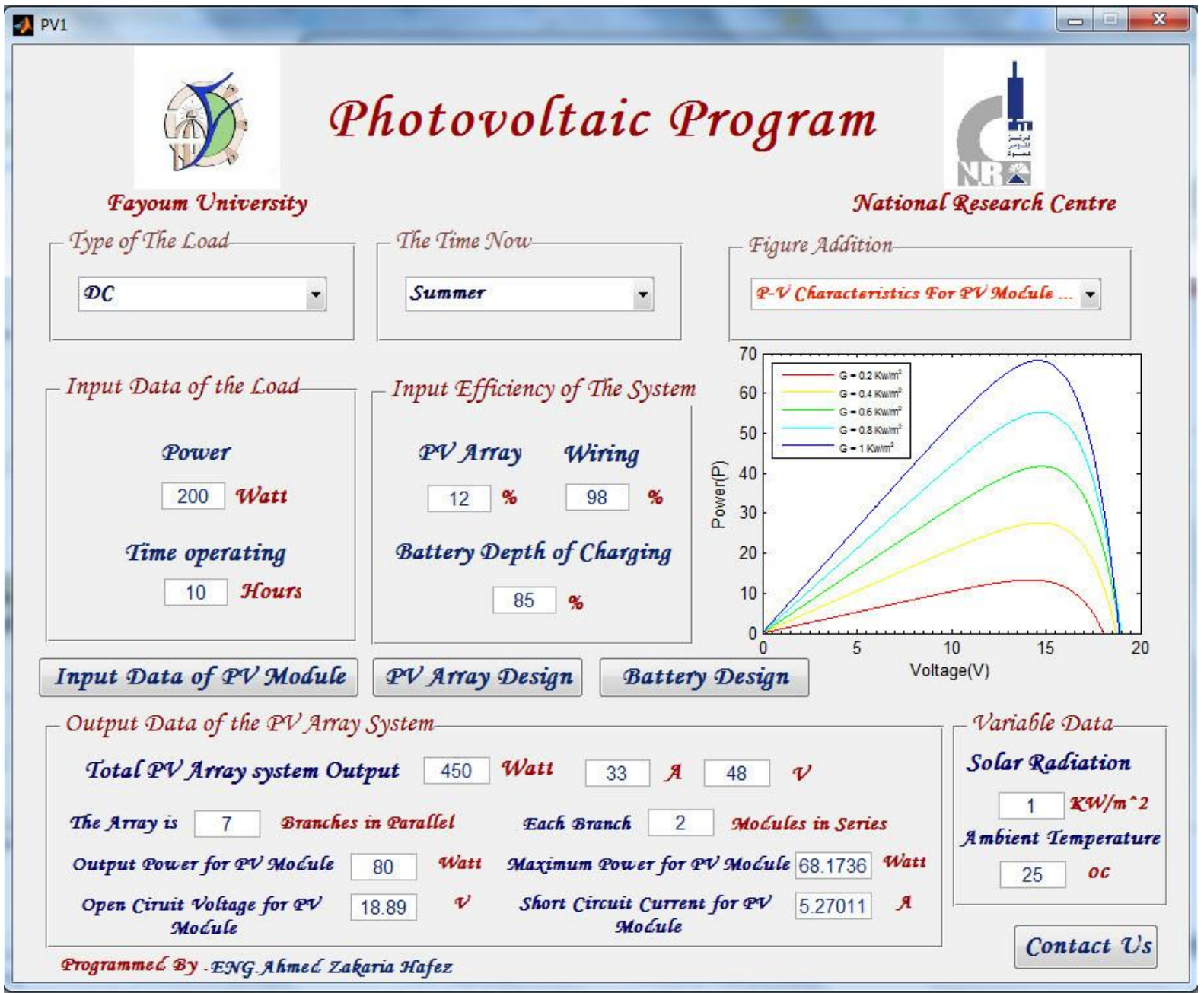

(a)

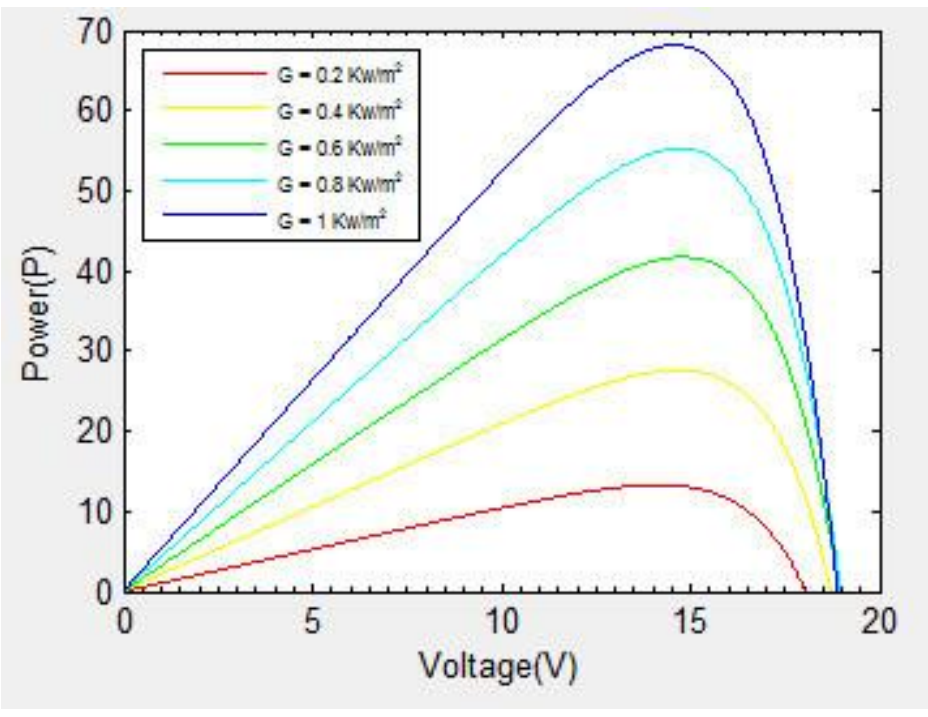

(b)

Fig. 11: Effects of solar radiation changes in (P-V) characteristics of PV Module at constant temperature $\left(25^{\circ} \mathrm{C}\right)$ (a) Matlab GUI/Interface simulation model (b) (P-V) characteristics figures of PV Module 


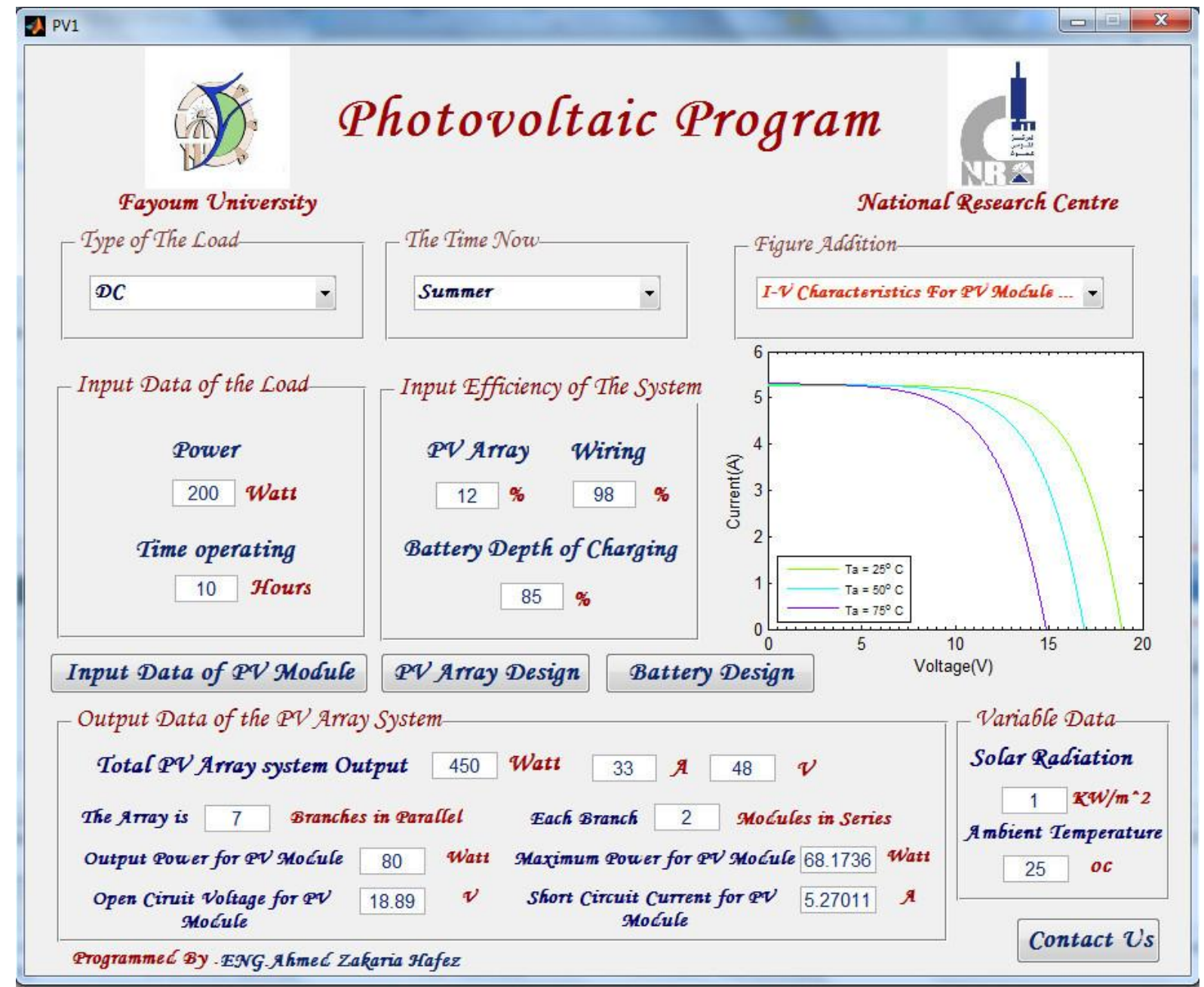

(a)

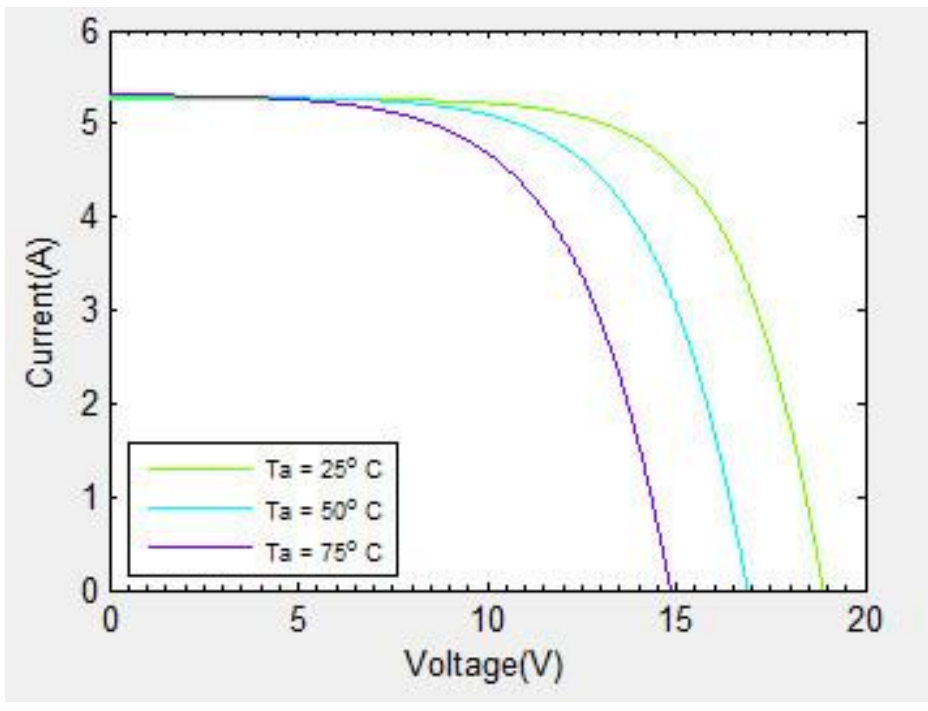

(b)

Fig. 12: Effects of temperature changes in (I-V) characteristics of PV Module at constant solar radiation $\left(1 \mathrm{kw} / \mathrm{m}^{2}\right)$ (a) Matlab GUI/Interface simulation model (b) (I-V) characteristics figures of PV Module 


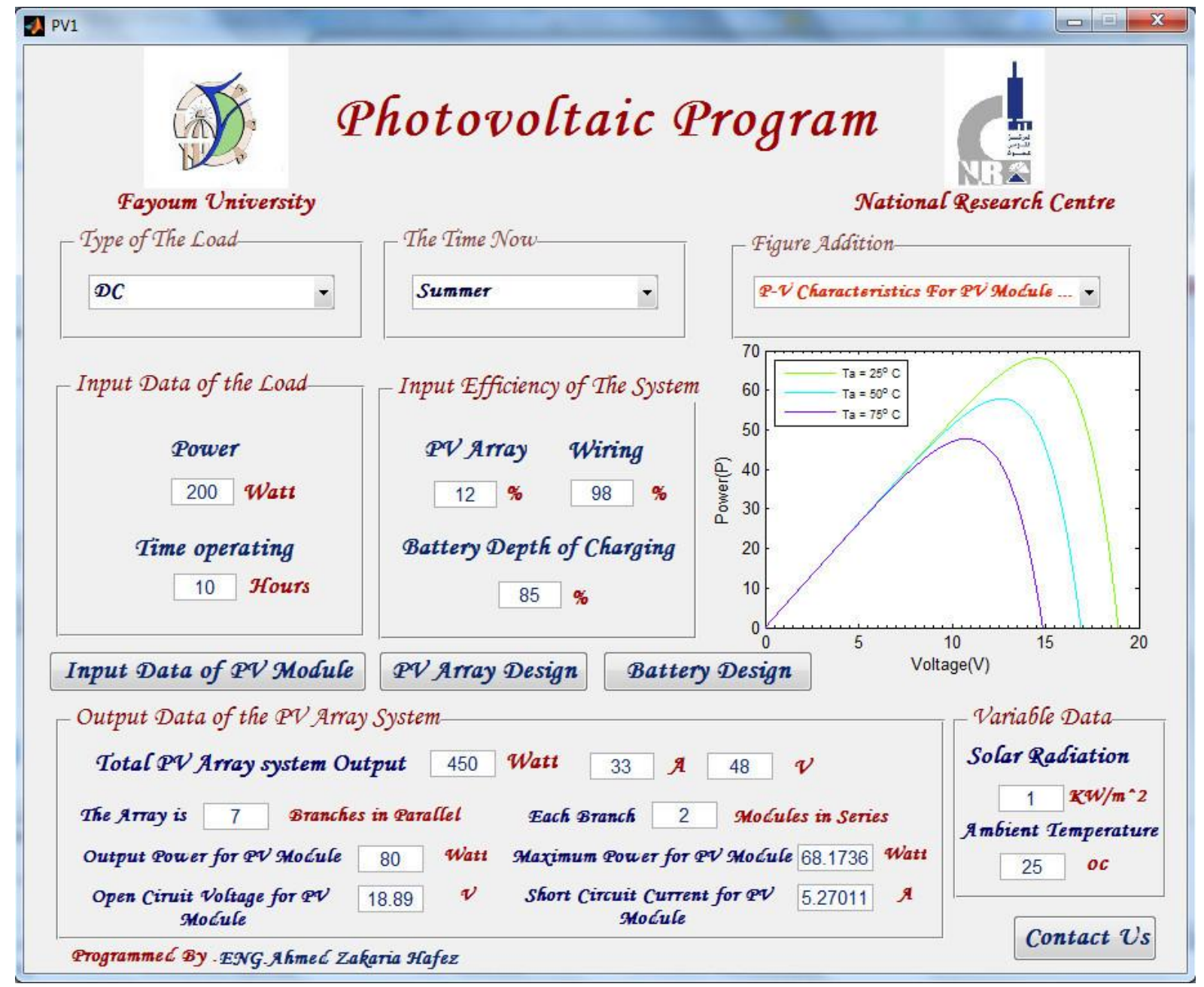

(a)

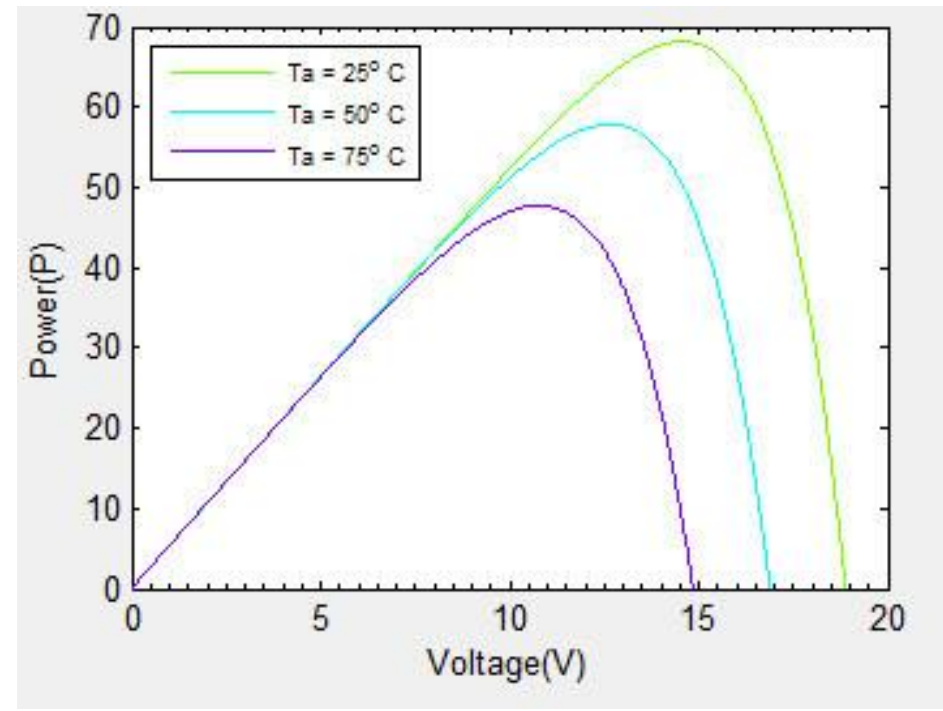

(b)

Fig. 13: Effects of temperature changes in (P-V) characteristics of PV Module at constant solar radiation $\left(1 \mathrm{kw} / \mathrm{m}^{2}\right)$ (a) Matlab GUI/Interface simulation model (b) (P-V) characteristics figures of PV Module 


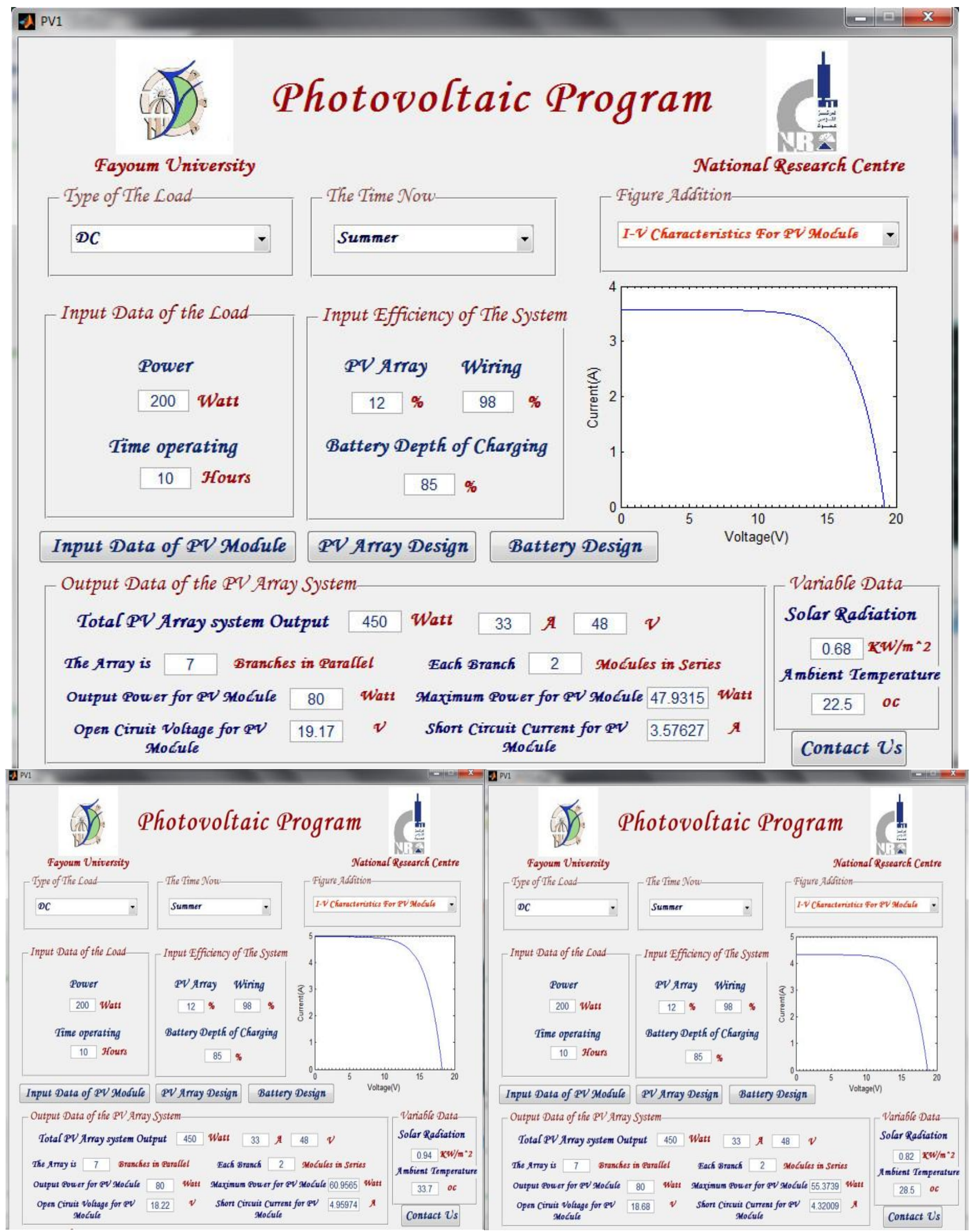

Fig. 14: Effects of Solar radiation \& temperature changes in real time operation in (I-V) characteristics of PV Module 


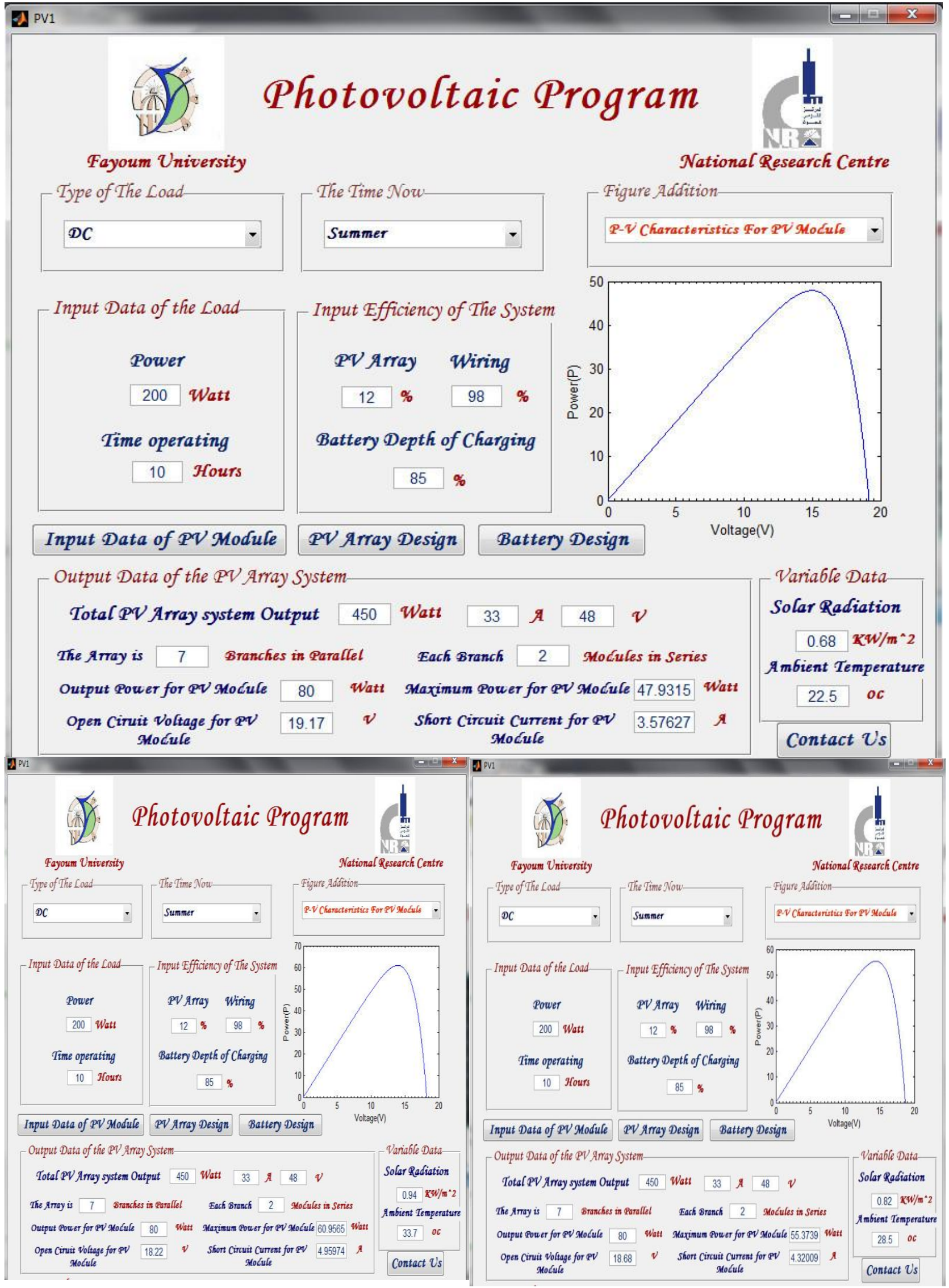

Fig. 15: Effects of Solar radiation \& temperature changes in real time operation in (P-V) characteristics of PV Module 


\section{CONCLUSION}

A photovoltaic (cell, module and array) simulation model is developed and presented in this paper to be used in MATLAB $® / G U I$ interface environment.

By DAQ, Data are inserted of solar insolation and temperature, the model calculates the current and voltage by Newton-Raphson method. The results from the MATLAB ${ }^{\circledR} /$ GUI interface model show excellent correspondence to manufacturer's published curves. Finally the model development was used to show the effect of: insolation, temperature in real time as monitoring system for the current - voltage (I-V) characteristics \& the power voltage $(\mathrm{P}-\mathrm{V})$ characteristics and design for $\mathrm{PV}$ array system design.

\section{ACKNOWLEDGMENTS}

Authors would like to thank National Research Centre (NRC) and Fayoum University for supports to do this work.

\section{REFERENCES}

[1] Afrouzi, H.N., Mashak, S.V.,Dastgheib,A.M.,andTavalaei,J.2011. Economic Sizing of Solar Array for a Photovoltaic Building in Malaysia with Matlab, First International Conference on Informatics and Computational Intelligence, 306-311.

[2] Sukamongkol, Y., Chungpaibulpatana S., and Ongsakul,W. 2002. A simulation model for predicting the performance of a solar photovoltaic system with alternating current loads, Renewable Energy 27 (2) 237 258.

[3] Joshi,A.S.,Dincer,I., and Reddy, B.V. 2009. Performance analysis of photovoltaic systems: a review, Renewable and Sustainable Energy Reviews 13 (8) 1884-1897.

[4] Eltawil, M.A.and Zhao, Z. 2010. Grid-connected photovoltaic power systems: Technical and potential problems - a review, Renewable and Sustainable Energy Reviews 14 (1) 112-129.

[5] De Blas, M.A., Torres, J.L.,Prieto, E., and Garcia,A. 2002. Selecting a suitable model for characterizing photovoltaic devices, Renewable Energy 25 (3) 371-380.

[6] Alonso-Garcia,M.C. andRuiz,J.M. 2006. Analysis and modelling the reverse characteristic of photovoltaic cells, Solar Energy Materials and Solar Cells 90 (7-8) 11051120.

[7] Soto,W.D., Klein, S., and Beckman,W. 2006. Improvement and validation of a model for photovoltaic array performance, Solar Energy 80 (1) 78-88.

[8] Chenni, R.,Makhlouf,M.,Kerbache, T., and Bouzide, A. 2007. A detailed modeling method for photovoltaic cells, Energy 32 (9) 1724-1730.

[9] Celik,A.N. and Acikgoz, N. 2007. Modelling and experimental verification of the operating current of mono-crystalline photovoltaic modules using four- and five-parameter models, Applied Energy 84 (1) 1-15.

[10] Jung,J.H. and Ahmed,S. 2012. Real-time simulation model development of single crystalline photovoltaic panels using fast computation methods, Solar Energy 86 $1826-1837$.

[11] Sukamongkol,Y., Chungpaibulpatana,S., and Ongsakul,W. 2002. A simulation model for predicting the performance of a solar photovoltaic system with alternating current loads, Renewable Energy 27 (2) 237 258.

[12] Jones,A.D. and Underwood,C.P. 2011. A thermal model for photovoltaic systems, Solar Energy 70 (4) 349-359.

[13] Ali. 2005. Characteristics of flow and heat transfer for in-line plate segments inside channel used for photovoltaic modules thermal regulation, Applied Thermal Engineering 25 (8-9) 1381-1401.

[14] Dehra,H. 2009. A two dimensional thermal network model for a photovoltaic solar wall, Solar Energy 83 (11) 1933-1942.

[15] Tina,G.M. and Abate,R. 2008. Experimental verification of thermal behaviour of photovoltaic modules, In: Proc IEEE Mediterranean Electrotechnical Conf. 579-584.

[16] Gil-Arias, O. and Ortiz-Rivera, E.I. 2008. A general purpose tool for simulating the behavior of pv solar cells, modules and arrays, In: 11th Workshop on Control and Modeling for Power Electronics. 1-5.

[17] Skoplaki,E. and Palyvos, J. 2009. On the temperature dependence of photovoltaic module electrical performance: a review of efficiency/ power correlations, Solar Energy 83 (5) 614-624.

[18] Villalva, Marcelo Gradella, Gazoli, Jonas Rafael, Filho andErnesto Ruppert. 2009. Comprehensive approach to modeling and simulation of photovoltaic arrays, IEEE Trans. Power Electron 24 (5) 1198-1208.

[19] Moradi, M.H. andReisi,A.R. 2011. A hybrid maximum power point tracking method for photovoltaic systems Solar Energy 85, 2965 - 2976.

[20] Buresch, M. 1983. Photovoltaic Energy Systems Design and Installation,McGraw-Hill, New York.

[21] Francisco,M. and González-Longatt. 2005. Model of Photovoltaic Module in Matlab ${ }^{\mathrm{TM}}$, 2do congresoiberoamericano de estudiantes de ingenıeríaeléctrica, electrónıca y computación 1-5.

[22] Atlas, I. and Sharaf,A. 2007. A photovoltaic array simulation model for matlab-simulinkgui environment, in International Conference on Clean Electrical Power 341 -345 .

[23] Alsayid,B. andJallad, J. 2011. Modeling and Simulation of Photovoltaic Cells/Modules/Arrays, IJRRCS 2 (6) 1327-1331.

[24] Tsai, H.L., Tu, C.S., and Su, Y.J. 2008. Development of Generalized Photovoltaic Model Using MATLAB/SIMULINK, Proceedings of the World Congress on Engineering and Computer Science WCECS, San Francisco, USA.

[25] Villalva, M.G., Gazoli, J.R, and Filho,E.R 2009.Comprehensive approach to modeling and simulation of photovoltaic array, IEEE Trans on Power Electronics 24 (5) 1198-1208.

[26] Chaouachi, A.,Kamel,R.M., and Nagasaka,K. 2010. A novel multi-model neuro-fuzzy-based MPPT for threephase grid-connected photovoltaic system, Solar Energy 84 (2010) 2219 - 2229. 